\title{
Assessment of River Ecological Quality Using B-IBI (Dez River, Southwestern of Iran)
}

\author{
Maryam Mohammadi Rouzbahani, Nasrin Roghani zadehgan, and Amir Harirforoush
}

\begin{abstract}
The aim of this study is to develop a benthic index of biotic integrity (B-IBI) to help understand how the increasing anthropogenic pressure may impact the permanent Dez River in Iran. For this propose, 5 sampling stations with 4 replicates has been selected from January 2012 to June 2013. Also physiochemical parameters of water, grain size analysis and percentage total organic matter (TOM) of sediment was determined. We selected ten metrics for the final IBI. 19 species from 12 families of macrobenthose have been identified. The highest abundance was belong to Oligocheates with $80 \%$ and the lowest was belong to Gastropoda with $14.5 \%$. The results of $B$-IBI showed that most sites were in fairly poor condition. These results suggest that the B-IBI may be a suitable method for assessing Dez river conditions and other rivers with same weathering and ecological conditions.
\end{abstract}

Index Terms-River pollution, benthic macro-invertebrates, biomonitoring, Dez River.

\section{INTRODUCTION}

Since aquatic ecosystems such as streams and rivers are among the most endangered ecosystems worldwide, there are urgent demands for comprehensive methodological approaches to evaluate the actual state of these ecosystems and to monitor their rate of change [1], [2]. Part of the decline in water resources stems from insufficient consideration of their biological structure and function [2].

Some factors have been reported which are linked to river degradation. Physical and chemical factors may be related to biological changes [3]. Water quality may only partially reflect environmental impact [1]. Physical, chemical and bacteriological measurements commonly form the basis of monitoring, because they provide complete spectrum of information for proper water management [4]. However, in running waters, where changes in hydrology are rapid and difficult to estimate, they cannot reflect the integration of numerous environment factors and long-term sustainability of river ecosystems for their instantaneous nature. Therefore biomonitoring has been proven to be necessary supplementary to those traditional monitoring techniques [5]. Biological indicators are especially useful in a comprehensive water quality program as they reflect the habitat conditions in the aquatic system as well as water quality conditions over a longer term than noncontinuous water quality sampling. Several types of organisms can be used in biological monitoring such as fish [1], invertebrates, and periphyton, however, the Benthic Index of Biotic

Manuscript received October 25, 2014; revised December 30, 2014.

Maryam Mohammadi Rouzbahani, Nasrin Roghani zadehgan, and Amir Harirforoush are with the Department of Environmental Science, College of the Agriculture and Natural Resources, Ahvaz Branch, Islamic Azad University, Ahvaz, Iran (e-mail: mmohammadiroozbahani@yahoo.com).
Integrity (B-IBI) uses benthic invertebrates (or invertebrates found in stream substrate) and has been successfully and cost-effectively incorporated into many water quality monitoring programs worldwide [1], [6].

The B-IBI is based on a series of structural and functional metrics of benthic macroinvertebrate assemblages, and thus helps quantify the impact of environmental deterioration [2].

The purpose of this research is to develop a benthic IBI (B-IBI) for the Dez River in southwestern Iran to reflect anthropogenic stresses on river.

\section{MATERIALS AND METHODS}

The present study was conducted on the Dez River, in Khuzestan province, southwestern Iran. This river is one of the most important rivers in Iran. Data were obtained from 5 stations from January 2012 to June 2013 in the middle of each season (Fig. 1).

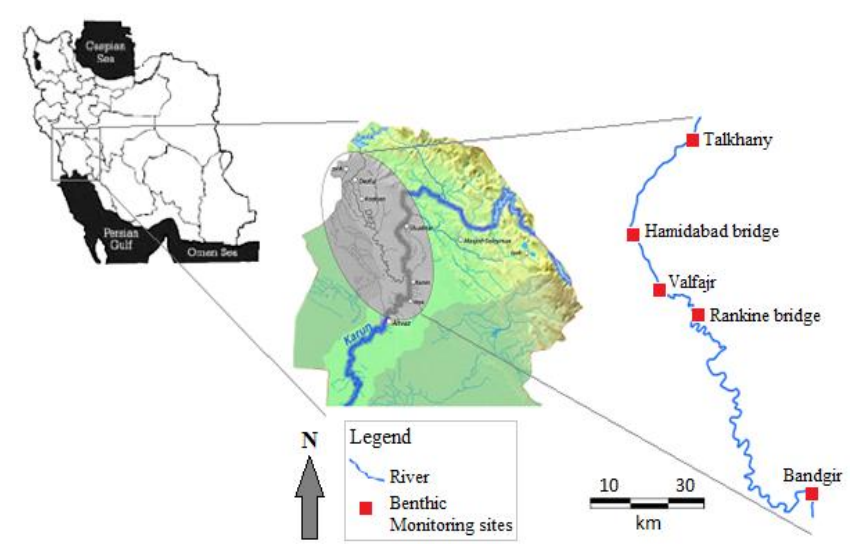

Fig. 1. The location of stations in Dez River (2012-2013).

Physicochemical parameters of water such as salinity (PSU), temperature $\left({ }^{\circ} \mathrm{C}\right)$, dissolved oxygen $(\mathrm{mg} / \mathrm{l}), \mathrm{pH}$ (units) and conductivity ( $\mu \mathrm{s})$ were determined in seasons using Hydrolab multimeter (HORIBA, U10). Samples were collected using a Vanveen grab $\left(0.025 \mathrm{~m}^{2}\right)$ taking four replicates at each station. 3 replicates for macrobenthose analysis and 1 sample with three replicates for grain size and total organic matter of the sediment were considered. In stations that grain size of sediments was high, used Surber net for sampling Macrobenthose communities. Macrobenthose samples were sieved on a board with a 0.5 $\mathrm{mm}$ mesh size, preserved in 5\% formalin solution in sea water and then transferred to the laboratory. The samples were preserved in $99 \%$ ethanol and then transferred into 1 $\mathrm{g} / \mathrm{l}$ of Rose Bengal solution stain for identification [7]. Benthic species were sorted under a dissecting microscope using 16x magnification and all macroinvertebrates were identified to the lowest possible taxonomic level, often to family level, by use of systematic and classification keys. 
Previous studies have shown that this level of taxonomic resolution is cost-effective and is sufficient for detecting effects associated with a variety of anthropogenic disturbances. In order to determine distribution of sediment particle size, the first part of each sample was dried at $70^{\circ} \mathrm{C}$ for $48 \mathrm{~h}$ and sieved through a nested series of sieves. The other part of each sample was first dried at $70^{\circ} \mathrm{C}$ for $48 \mathrm{~h}$ and then combusted at $550^{\circ} \mathrm{C}$ for $60 \mathrm{~min}$ to determine the total organic matter content through weight loss [8]. Then benthic index include B-IBI has been determined using 10 criteria that was needed. The B-IBI is based on a series of structural and functional metrics of benthic macroinvertebrate assemblages. Structural B-IBI components include species richness, habitat guilds, trophic structure, organismal abundance and biodiversity. Functional components consist of feeding and trophic categories, environmental tolerance, and individual stress and condition groupings. The index component of the B-IBI description indicates that several types of data are synthesized into a single number that depicts overall biological condition. The B-IBI is a multi-metric index in which several metrics of the invertebrate community are calculated, and given a score, and then those scores are combined to give the index value. Metrics such as the number of pollution tolerant taxa, the total number of taxa, and population attributes such as the number of long-lived taxa or predator taxa are used to assess the health of the community. These metrics, once combined into a single index score, indicate the relative health of the system and are correlated to ratings and descriptions. The ratings used for this analysis consist of the following: Healthy, Compromised, Impaired, Highly Impaired, and Critically Impaired [5]. The B-IBI is both habitat and season dependent. Therefore data must be selected for time of year and pre-classified according to the habitat type from which the samples were collected. The biological metrics for stream invertebrates, response to human disturbance, and scoring rules used to integrate into the B-IBI presented in Table I. Also B-IBI classifications of stream conditions are shown in Table II. Data analyses were made using the Statistical Package for the Social Sciences (SPSS) version 13.

TABLE I: BIOLOGICAL METRICS FOR STREAm INVERTEBRATES, RESPONSE TO HumAn DisturbanCE, AND SCORING RULES USED TO INTEGRATE INTO THE B-IBI

\begin{tabular}{|c|c|c|c|c|}
\hline \multirow{2}{*}{ Metrics: Taxa richness and composition } & \multirow{2}{*}{ Response } & \multicolumn{3}{|c|}{ Scoring Criteria } \\
\hline & & 1 & 3 & 5 \\
\hline Total number of taxa ${ }^{1}$ & Decrease & {$[0,14)$} & {$[14,28]$} & $>28$ \\
\hline Number of Ephemeroptera taxa ${ }^{1}$ & Decrease & {$[0,3.5)$} & {$[3.5,7]$} & $>7$ \\
\hline Number of Plecoptera taxa ${ }^{1}$ & Decrease & {$[0,2.7)$} & {$[2.7,5.3]$} & $>5.3$ \\
\hline Number of Trichoptera taxa ${ }^{1}$ & Decrease & {$[0,2.7)$} & {$[2.7,5.3]$} & $>5.3$ \\
\hline Number of long-lived taxa ${ }^{2}$ & Decrease & {$[0,4)$} & {$[4,8]$} & $>8$ \\
\hline \multicolumn{5}{|l|}{ Tolerance } \\
\hline Number of intolerant taxa ${ }^{2}$ & Decrease & {$[0,2)$} & {$[2,4]$} & $>4$ \\
\hline$\%$ of individuals in tolerant taxa ${ }^{1}$ & Increase & $>44$ & {$[44,27]$} & $27>$ \\
\hline \multicolumn{5}{|l|}{ Feeding ecology } \\
\hline$\%$ of predator individuals ${ }^{1}$ & Decrease & {$[0,4.5)$} & {$[4.5,9]$} & $>9$ \\
\hline Number of clinger taxa ${ }^{1}$ & Decrease & {$[0,8)$} & {$[8,16]$} & $>16$ \\
\hline \multicolumn{5}{|l|}{ Population attributes } \\
\hline$\%$ dominance $(3 \text { taxa })^{3}$ & Increase & $\geq 75$ & $(75,55]$ & $55>$ \\
\hline
\end{tabular}

1 mean of three replicates, 2 cumulative of three replicates, 3 three of the most abundant taxa

TABLE II: B-IBI CLASSIFICATIONS OF STREAM CONDITION, DESCRIPTION AND RANGE OF VALUES

\begin{tabular}{|l|l|l|}
\hline B-IBI values & Site condition & Description \\
\hline $50-46$ & Healthy & Ecologically intact, supporting the most sensitive life-forms. \\
\hline $44-36$ & Compromised & Showing signs of ecological degradation. Impacts expected to one or more salmon life-stages. \\
\hline $34-28$ & Impaired & Healthy ecosystem functions demonstrably impaired. Cannot support self-sustaining salmon populations. \\
\hline $26-18$ & Highly impaired & Highly adverse to salmon and various other life-forms. \\
\hline $16-10$ & Critically impaired & Unable to support a large proportion of once-native life-forms. \\
\hline
\end{tabular}

TABLE III: DISTRIBUTION OF IDENTIFIED MACROBENTHOS SPECIES IN DEZ RIVER (N/M²)

\begin{tabular}{|c|c|c|c|c|c|c|c|c|}
\hline \multicolumn{3}{|c|}{ Species } & Tubifex tubifex & $\begin{array}{l}\text { Specaria } \\
\text { josinae }\end{array}$ & $\begin{array}{l}\text { sp. } \\
\text { Erpobdella }\end{array}$ & $\begin{array}{l}\text { Chironomus } \\
\text { riparius }\end{array}$ & $\begin{array}{l}\text { Hermetia } \\
\text { illucens }\end{array}$ & $\begin{array}{l}\text { Corbicula } \\
\text { fluminea }\end{array}$ \\
\hline \multicolumn{3}{|c|}{ Family } & Tubificidae & Naididae & Erpobdellidae & Chironomidae & Stratiomyidae & Corbicolidae \\
\hline \multicolumn{3}{|c|}{ Class } & \multicolumn{2}{|c|}{ Oligochaeta } & Hirudinea & \multicolumn{2}{|c|}{ Insecta } & Bivalvia \\
\hline \multirow{4}{*}{ Summer(2013) } & \multirow{4}{*}{ Station } & 1 & $2717.6 \pm 5427$ & $919.6 \pm 7979$ & - & $52.9 \pm 103$ & - & - \\
\hline & & 2 & - & $485.7 \pm 5256$ & - & $312.2 \pm 396$ & - & $118 \pm 118$ \\
\hline & & 3 & - & $1891 \pm 3755$ & - & $242 \pm 396$ & - & $132 \pm 132$ \\
\hline & & 4 & - & - & - & - & - & - \\
\hline
\end{tabular}




\begin{tabular}{|l|c|c|c|c|c|c|c|c|}
\hline & & $\mathbf{5}$ & $14.7 \pm 161$ & - & $67.2 \pm 176$ & - & - & - \\
\hline \multirow{5}{*}{ Winter(2012) } & $\mathbf{1}$ & $1652 \pm 9739$ & $704.6 \pm 16133$ & - & $77.6 \pm 117$ & - & - \\
\cline { 3 - 10 } & \multirow{4}{*}{ Station } & $\mathbf{2}$ & - & $4429 \pm 9621$ & - & $586.7 \pm 675$ & - & $264 \pm 264$ \\
\cline { 3 - 10 } & & $\mathbf{3}$ & - & $4956 \pm 9093$ & - & $854.7 \pm 1144$ & $29 \pm 29$ & $410.7 \pm 763$ \\
\cline { 3 - 10 } & & $\mathbf{4}$ & - & - & - & - & - & - \\
\cline { 3 - 10 } & & $\mathbf{5}$ & $187.3 \pm 337$ & - & $163.3 \pm 601$ & - & - & - \\
\hline
\end{tabular}

\begin{tabular}{|c|c|c|c|c|c|c|c|c|c|c|c|}
\hline $\begin{array}{c}\text { Tryonia } \\
\text { clathrata }\end{array}$ & $\begin{array}{l}\text { Tryonia } \\
\text { exigua }\end{array}$ & $\begin{array}{l}\text { Bithynia } \\
\text { tentaculata }\end{array}$ & $\begin{array}{l}\text { Melanopsis } \\
\text { frustulum }\end{array}$ & $\begin{array}{c}\text { Melanopsis } \\
\text { attenuata }\end{array}$ & $\begin{array}{l}\text { Melanopsis } \\
\text { buccinoidea }\end{array}$ & $\begin{array}{l}\text { Physella } \\
\text { acuta }\end{array}$ & $\begin{array}{c}\text { Nerita } \\
\text { funiculate }\end{array}$ & $\begin{array}{l}\text { Theodoxus } \\
\text { danubialis }\end{array}$ & $\begin{array}{c}\text { Neritodryas } \\
\text { dubia }\end{array}$ & $\begin{array}{l}\text { Theodoxus } \\
\text { fluviatilis }\end{array}$ & $\begin{array}{l}\text { Pettancylus } \\
\text { nipponicus }\end{array}$ \\
\hline \multicolumn{2}{|c|}{ Hydrobiidae } & Bithyniidae & \multicolumn{3}{|c|}{ Melanopsidae } & Physidae & \multicolumn{4}{|c|}{ Neritidae } & Ferrissidae \\
\hline \multicolumn{12}{|c|}{ Gastropoda } \\
\hline- & - & - & - & - & - & - & - & - & - & - & - \\
\hline- & - & $101.6 \pm 176$ & $140 \pm 513$ & $103 \pm 205$ & - & $94 \pm 117$ & $103 \pm 249$ & $76 \pm 132$ & - & - & - \\
\hline $44 \pm 44$ & - & $191 \pm 191$ & $177.8 \pm 484$ & $64 \pm 191$ & $132 \pm 132$ & - & $278.6 \pm 645$ & $114.6 \pm 205$ & $101.6 \pm 176$ & - & $89.2 \pm 161$ \\
\hline- & - & - & - & - & - & - & - & - & - & - & - \\
\hline- & - & - & - & - & - & - & - & - & - & - & - \\
\hline- & - & - & - & - & - & - & - & - & - & - & - \\
\hline- & - & $110.7 \pm 308$ & $191.8 \pm 352$ & $116 \pm 792$ & $91.6 \pm 132$ & $470 \pm 470$ & $338 \pm 499$ & - & $411 \pm 411$ & - & $29 \pm 29$ \\
\hline $29 \pm 29$ & $29 \pm 29$ & $152 \pm 396$ & $255.7 \pm 411$ & $383.6 \pm 1012$ & $205 \pm 205$ & $59 \pm 59$ & $487 \pm 895$ & $96.2 \pm 601$ & $471 \pm 1203$ & $165.3 \pm 293$ & $331 \pm 557$ \\
\hline- & - & - & - & - & - & - & - & - & - & - & - \\
\hline- & - & - & - & - & - & - & - & - & - & - & - \\
\hline
\end{tabular}

\section{RESULTS AND DisCUSSION}

In this study we collected and identified 18 macroinvertebrate taxa. Several taxa were ubiquitous among moderate- to minimum-influence sites, especially genera in the families Naididae and Chironomidae. Chironomids were the only taxon at sites with severe point-source pollution. The identified macrobenthos species in Dez River are shown in Table III.

Abundance percentage of Macrobenthos classes showed that $80 \%$ belong to Oligochaeta (Fig. 2).

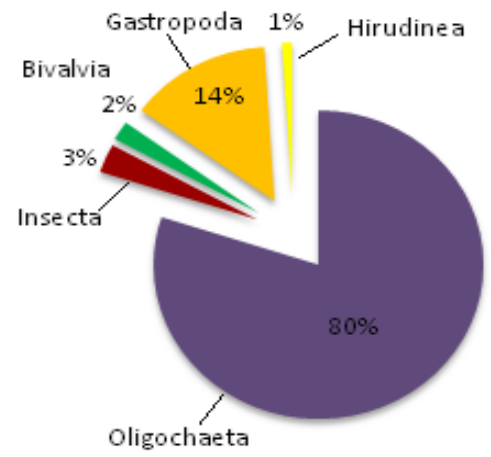

Fig. 2. Abundance Percentage of Macrobenthos classes in Dez River (20122013).

The measured results of physico-chemical parameters of water showed that there were significant differences between physico-chemical parameters of water in the stations of seasons $(P<0.05)$. The results of physicochemical parameters during two seasons showed little fluctuations $(P>0.05)$. The minimum amount of temperature belongs to station1 in winter $(14.47 \pm 0.47)$ and maximum amount belong to station3 in summer $(31.3 \pm 0.75)$. Along two seasons, highest amount of turbidity $(69.17 \pm 9.17)$ and EC (2002.5 \pm 12.5$)$ belong to station5.

The results of the grain size analysis are shown in Fig. 4. The results showed that more than $68 \%$ of the grain size of the sediment in station 3 were $>0.125$, and in other stations more than $65 \%$ of sediments were $<0.063 \mathrm{~mm}$.

TABLE IV: SEASONAL VALUES OF B-IBI IN DEZ RIVER (2012-2013)
\begin{tabular}{|c|c|c|c|c|}
\hline \multirow{2}{*}{ Sites } & \multicolumn{3}{|c|}{ B-IBI } & $\begin{array}{c}\text { Site } \\
\text { Condition }\end{array}$ \\
\cline { 2 - 4 } & Winter & Summer & Entire period & Critically impaired \\
\hline 1 & 12 & 12 & 12 & Highly impaired \\
\hline 2 & 18 & 18 & 18 & Highly impaired \\
\hline 3 & 22 & 18 & 20 & Azoic \\
\hline 4 & Azoic & Azoic & Azoic & Critically impaired \\
\hline 5 & 16 & 16 & 16 & \\
\hline
\end{tabular}

The results of the total organic matter of sediment analysis are shown in Fig. 5. The highest mean of percentage TOM was obtained in winter $(5.04 \%)$ and the lowest obtained in summer $(4.48 \%)$. The highest amount of TOM in two seasons belongs to station4 with the mean $9.35 \%$ and the minimum belong to station 3 with the mean $2.01 \%$. According to statistical analysis, there were significant differences between percentage TOM of sediment in seasons and stations $(P<0.05)$.

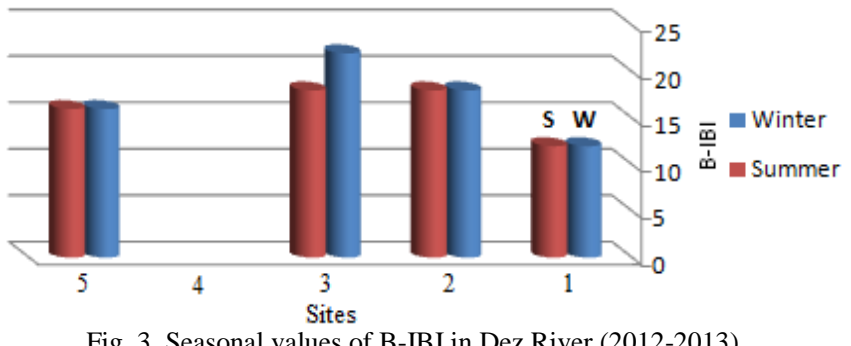

Fig. 3. Seasonal values of B-IBI in Dez River (2012-2013). 


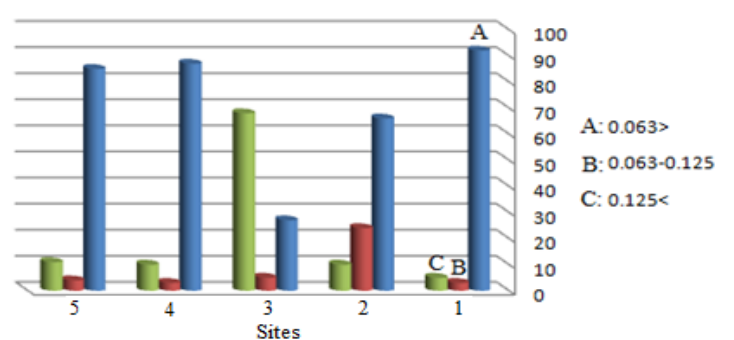

Fig. 4. The percent of sediment grain size in Dez River (2012-2013).

The B-IBI results showed that stations classified as highly impaired and critically impaired (Table IV). Also one of the stations (station4) classified as Azoic because of there wasn't any macronethose species in this station. It shows that there is very high pollution in this station (Fig. 3).

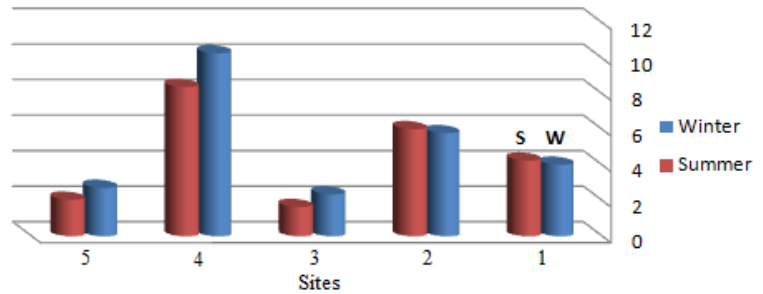

Fig. 5. Total organic matter percent of sediments in Dez River (2012-2013).

\section{CONCLUSION}

On the basis of B-IBI results, study area classified as highly impaired and critically impaired. Also one of the stations (station4) classified as Azoic because of there wasn't any macronethose species in this station. It shows that very high pollution in this station. It is similar to Morley et al. study at 1999 [9]. Physiochemical parameters of water, total organic matters and grain size of sediments are important factors that effect on diversity and frequency of macrobenthose communities. This is proved by Boyle and Fraleigh, 2003. The presence and absence of macrobenthose in rivers shows natural and anthropogenic effects. In this research, Oligochatea with highest frequency belong to station1. This station has a severe pollution because of effluent of sewage effluent without any treatment. The results from polluted stations is proved by B-IBI and this is confirmed by Saunders et al., 2007 [10]. Highest frequency of Oligochatea is a good index for organic pollutions. An important point about resulting from B-IBI is that considering the sampling site conditions. Effluent of agricultural, industrial and anthropogenic pollutants to Dez River, caused to depleting sensitive groups of macrobenthose. We propose that this index will be used in other rivers for assessing ecological quality of them.

\section{REFERENCES}

[1] J. R. Karr, "Rivers as sentinels: Using the biology of rivers to guide landscape management," in River Ecology and Management: Lessons from the Pacific Coastal Ecosystem, R. J. Naiman and R. E. Bilby, Eds. NY: Springer, 1998, pp. 502-528.

[2] J. R. Karr, J. D. Allan, and A. C. Benke, "River conservation in the United States and Canada: science, policy, and practice," in River
Conservation: Science, Policy, Practice, P. J. Boon, B. R. Davies, and G. E. Petts, Eds. London: J. Wiley, 1999.

[3] J. R. Karr and D. R. Dudley, "Ecological perspective on water quality goals," Environmental Management, vol. 5, pp. 55-68, 1981.

[4] J. R. Karr, "Defining and measuring river health," Freshwater Biology, vol. 41, pp. 221-234, 1999.

[5] M. T. Barbour, J. Gerritsen, G. E. Griffith, R. Frydenborg, E. McCarron, J. S. White, and L. Bastian, "A framework for biological criteria for Florida streams using benthic macroinvertebrates," $J$. North Am. Benthol., vol. 15, pp. 185-211, 1996.

[6] T. P. Boyle and H. D. Fraleigh, "Natural and anthropogenic factors affecting the structure of the benthic macroinvertebrate community in an effluent-dominated reach of the Santa Cruz River," AZ. Ecological Indicators, vol. 3, pp. 93-117, 2003.

[7] S. G. Walton, Hand Book of Marine Science, Cleveland: CRC Press, 1974, vol. 1, pp. 117-126.

[8] N. A. Holme and A. D. Mcintyre, Methods for Study of Marin Benthos, 2nd ed. Oxford Blackwell Scientific Publication, 1984, p. 387.

[9] S. A. Morley, "Effects of urbanization on the biological integrity of Puget Sound lowland streams:Restoration with a biological focus," MSc thesis, University of Washington, 2000.

[10] J. Saunders, M. Al Z. Kh, and D. Paterson, "The impact of organic pollution on the macrobenthic fauna of Dubai creek (UAE)," Marine Pollution Bulletin, vol. 11, pp. 1715-1723, 2007.

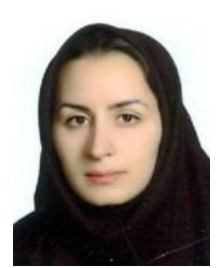

Maryam Mohammadi Rouzbahani was born in Borujerd, Iran on March 24, 1978. She received the B.Eng. degree in natural resources from Technical University of Isfahan, Iran in 2001, the M.Sc. and the $\mathrm{Ph} . \mathrm{D}$. degrees in environmental sciences from the Science and Research Branch, Islamic Azad University of Tehran, Iran, in 2004 and 2010, respectively.

She is currently an assistance professor in the Department of Agricultural and Natural Resources in Islamic Azad University of Ahwaz, Iran. From 2010 to 2013, she was the director of the environmental science group in Science and Research Branch of Islamic Azad university of Khouzestan. She has published more than 200 scientific papers in the field of environmental pollutions, biodiversity, water and soil pollutions. Her research interests include water pollution, monitoring of water ecosytems.

Dr. Mohammadi Rouzbahani is a member of the Society of Environmental Engineering of Iran (Sabz Pouyan Jonoob). She was a top researcher in the Science and Research Branch of Islamic Azad university of Khouzestan in 2011, 2012 and 2013 respectively.

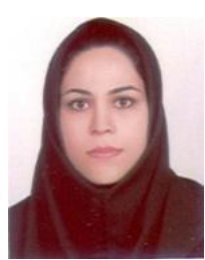

Nasrin Roghanizadehgan was born in St Khouzestan, Andimeshk, Iran on September 2, 1985. She received the B.Eng. degree (with honors) in natural resources-environment from the Shahid Chamran University of St. Khouzestan, Ahvaz in 2007, the M.Sc. degree in environmental pollution from the Ahvaz Branch, Islamic Azad University, Ahvaz, Iran in 2012.

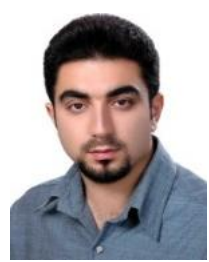

Amir Harirforoush was born in Masjed Soleyman, Iran in 1978. He received the engineering degree in natural resources from Allameh Mohadese Nouri University, Nour, Iran in 2001, M.Sc. degree in environmental sciences from Science and Research Branch of Islamic Azad university of Khouzestan, Iran in 2014 .

$\mathrm{He}$ works in agro industry of Hakim Farabi of Khouzestan since 2012. Also he cooperated in scientific research with Islamic Azad University of Ahwaz.

His main areas of research interest are land use management, assessment of ecosystems, water and soil pollutions.

Mr. Harirforoush is a member of the Society of Environmental Engineering of Iran(Sabz Pouyan Jonoob). 